\title{
A case of Uhl anomaly with right ventricular failure
}

\author{
*Sumitra Venkatesh ${ }^{1}$, Shakuntala Prabhu ${ }^{1}$, Mehul Thakkar ${ }^{2}$, Snehal Kulkarni $^{1}$
}

Sri Lanka Journal of Child Health, 2018; 47(1): 80-82

DOI: http://dx.doi.org/10.4038/sljch.v47i1.8437

(Key Words: Uhl anomaly, right ventricular failure)

\section{Introduction}

Uhl anomaly is a rare cardiac condition in which there is total absence of right ventricular myocardium. We report a case in a 10 month old boy.

\section{Case report}

A 10 month old boy, born of non-consanguineous parents was admitted with cough, cold and respiratory distress for 10 days. The child was developmentally normal. Antenatal history was not significant. A routine work-up was done, including chest $\mathrm{x}$-ray, which was suggestive of cardiomegaly (Figure 1).

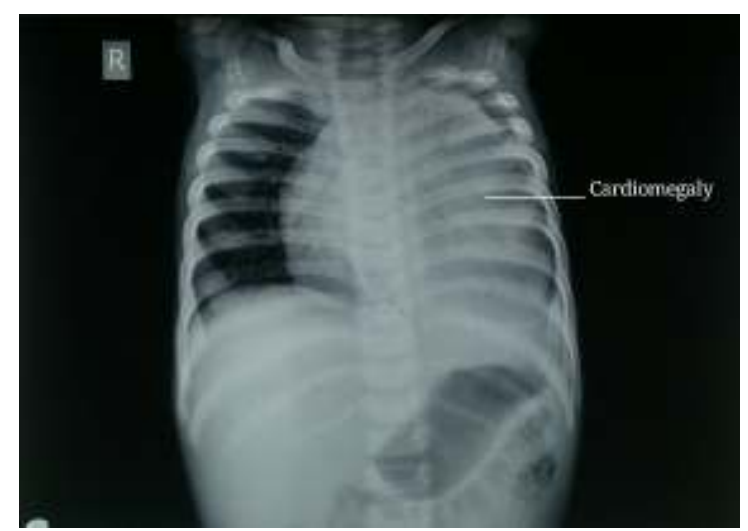

Figure 1: Chest $x$-ray showing cardiomegaly

Cardiac examination revealed findings suggestive of right heart failure like pedal oedema, tachycardia and hepatomegaly. 2D-echocardiography with colour Doppler revealed severe tricuspid regurgitation with significant right atrial and ventricular dilatation. The parchment like right ventricular free wall was devoid of myocardium, suggestive of Uhl anomaly (Figure 2).

\footnotetext{
${ }^{1}$ Seth GS Medical College and Bai Jerbai Wadia Hospital for Children, India, ${ }^{2}$ Seth GS Medical College and KEM Hospital, India

*Correspondence: sumitrav15@hotmail.com

(Received on 04 October 2016: Accepted after revision on 18 November 2016)

The authors declare that there are no conflicts of interest

Personal funding was used for the project.

Open Access Article published under the Creative

Commons Attribution CC-BY (CC) (P)
}

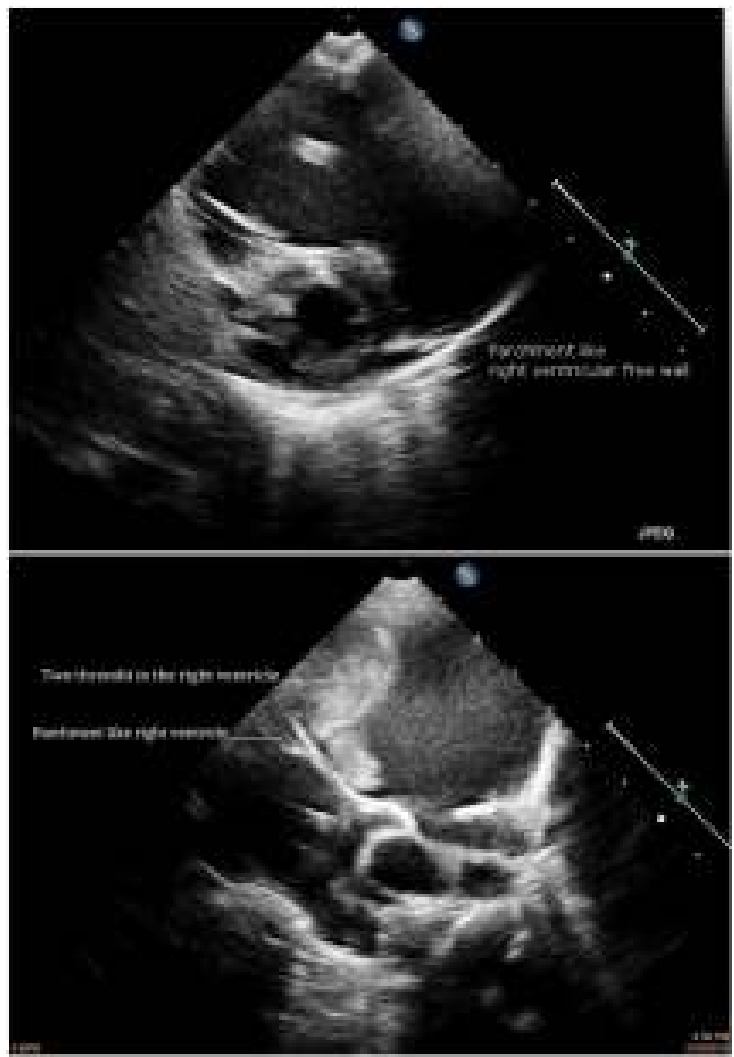

Figure 2: Echocardiographic findings

Additionally, two thrombi were seen in the right ventricular cavity with severe right ventricular dysfunction and significant dilatation of the right ventricular outflow tract. Electrocardiogram showed right atrial and ventricular hypertrophy. Cardiac magnetic resonance imaging done for further evaluation revealed voluminous dilatation of the right ventricle with absent visualization of the myocardium in the antero-lateral and posterior segment with an intact interventricular septum and a truncated right ventricular outflow tract, tricuspid valve being normal (Figure 3). Child was started on decongestive therapy with furosemide, antibiotics, enoxaparin sodium and sildenafil as medical management and is awaiting surgery. 


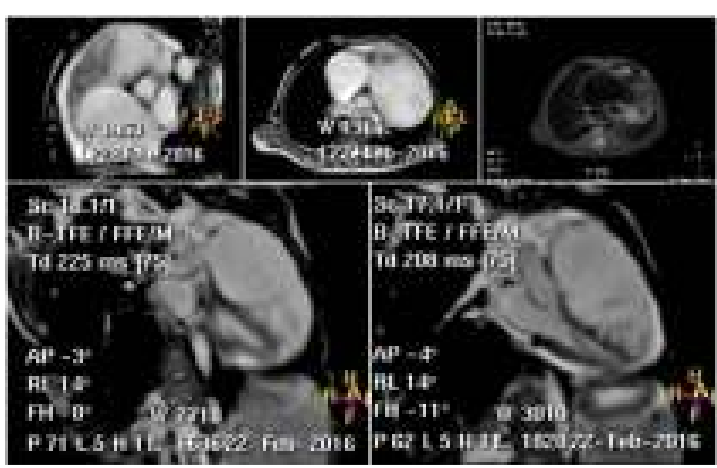

Figure 3: Cardiac magnetic resonance imaging

\section{Discussion}

Osler was the first to describe a thin, parchment-like heart where the ventricles were thin and dilated ${ }^{1}$. In 1952, Henry Uhl observed a thin right ventricle where the myocardial layer was absent ${ }^{2}$. This condition, now referred to as Uhl anomaly, is rare, and was revisited by Dr. Uhl more than 40 years after his original description ${ }^{3}$. It is not possible to estimate the prevalence of Uhl anomaly due to the extreme rarity of the condition. Most cases mentioned in the literature have only been studied post mortem for the same reason. Uhl anomaly consists of myocardial absence in right ventricle with apposing epicardial and endocardial layers and no adipose tissue present ${ }^{4,5}$. Uhl anomaly has often been confused with arrhythmogenic right ventricular dysplasia $^{5}$. In arrhythmogenic dysplasia, the right ventricular wall is replaced by fibrous and adipose tissues. In Uhl anomaly, the septal wall, septomarginal trabeculation and the papillary muscles of the tricuspid valve are normally muscularized $^{4,6}$. Patients with Uhl anomaly most commonly present with right sided heart failure ${ }^{7}$, as seen in our case. Cyanosis is often seen as a result of right to left shunting at the atrial level ${ }^{8}$. The cause of the absence of the myocardial layer is not fully known. It is postulated that it could result from apoptosis of the right ventricular myocardium or from failure to protect against apoptosis ${ }^{6,8,9}$. The underlying cause may be genetic due to a sporadic mutation ${ }^{4}$. Diagnosis is frequently made by imaging studies such as 2D-echocardiography or cardiac magnetic resonance imaging, and can be confirmed by myocardial biopsy. Myocardial biopsy was not performed in our case owing to parental nonconsent. Palliative treatment for congestive failure consists of standard forms of medication, including anti-arrhythmic drugs when indicated. Successful surgical repair has been reported in more recent times. The most frequent procedure has been right ventricular exclusion by closure of tricuspid valve orifice with atrial septectomy and a bi-directional Glenn shunt ${ }^{8}$. Cardiac transplantation has also been reported to have favourable outcomes in Uhl anomaly ${ }^{5}$.

\section{References}

1. Osler WM. The Principles and Practice of Medicine; $6^{\text {th }}$ ed. New York: D. Appleton; 1905. p. 280.

2. Uhl HS. A previously undescribed congenital malformation of the heart: Almost total absence of the myocardium of the right ventricle. Bulletin of the Johns Hopkins Hospital 1952; 91:197-209.

PMid: 12978573

3. Uhl HS. Uhl anomaly revisited. Circulation 1996; 93:1483-4. https://doi.org/10.1161/01.CIR.93.8.1483 PMid: 8608612

4. Gerlis LM, SchmidtOtt SC, Ho SY, Anderson RH. Dysplastic conditions of the right ventricular myocardium: Uhl anomaly vs arrhythmogenic right ventricular dysplasia. British Heart Journal 1993;69:142-50.

https://doi.org/10.1136/hrt.69.2.142

PMid: 8435240 PMCid: PMC1024941

5. Ikari NM, Azeka E, Aiello VD, Atik E, Barbero Marcial M, Ebaid M. Uhl anomaly. Differential diagnosis and indication for cardiac transplantation in an infant. Arq Bras Cardiol. 2001; 77:69-76. https://doi.org/10.1590/S0066782X20010 00700008

PMid: 11500750

6. Pamuru PR, Dokuparthi MV, Remersu S, Calambur N, Nallari P. Comparison of Uhl anomaly, right ventricular outflow tract ventricular tachycardia (RVOT VT) \& arrhythmogenic right ventricular dysplasia/cardiomyopathy (ARVD/C) with an insight into genetics of ARVD/C. Indian Journal of Medical Research 2010;131:3545.

PMid: 20167972

7. Richardson JD, Teo KS, Bertaso AG, Wong DT, Disney P, Worthley SG. Uhl anomaly. International Journal of Cardiology 2012;154:e36-7. https://doi.org/10.1016/j.ijcard.2011.05.00 5

PMid: 21640406 
8. Azhari N, Assaqqat M, Bulbul Z. Successful surgical repair of Uhl anomaly. Cardiology in the Young 2002;12:192-5. https://doi.org/10.1017/S10479511020004 10

PMid: 12018730

9. James TN, Nichols MM, Sapire DW, DiPatre PL, Lopez SM. Complete heart block and fatal right ventricular failure in an infant. Circulation 1996; 93:1588-600. https://doi.org/10.1161/01.CIR.93.8.1588

PMid: 8608628 